УДК 677.024.622:620.192.67

\title{
ИЗУЧЕНИЕ ВЛИЯНИЯ БИОДЕСТРУКТОРОВ НА ЦЕЛЛЮЛОЗУ И ПРИРОДНЫЕ ПРИМЕСИ ЛЬНОВОЛОКОН
}

\author{
() П.А. Морыганов" ${ }^{\text {* }}$ В.Н. Галашина, О.Ю. Кузнецов ${ }^{2}$ \\ ${ }^{1}$ Институт химии растворов им. Г.А. Крестова Российской академии наук, \\ ул. Академическая, 1, Иваново, 153045 (Россия), e-mail: poul.m@mail.ru \\ ${ }^{2}$ Ивановская государственная медицинская академия Минздравсоиразвития, \\ пр. Ф. Энгельса, 8, Иваново, 153012 (Россия)
}

\begin{abstract}
Исследованы особенности состава и структуры волокон льна как объектов воздействия микробных культур (МК), приведены сведения о динамике изменения содержания целлюлозы и сопутствующих ей природных примесей (пектиновых веществ, гемицеллюлоз, лигнина) в условиях культивирования индивидуальных МК и естественного комплекса микрофлоры. На примере нативных волокон селекционных сортов льна-долгунца Мерилин, Росинка и Эскалина показано, что снижение их разрывных нагрузок на 57-71\% в первые две недели воздействия МК в значительной мере обусловлено интенсивным разрушением компонентов клеящего лигноуглеводного комплекса (пектинов и гемицеллюлоз на 42-52\%). Выявлено, что развивающиеся на волокнах индивидуальные культуры Penicillum sp., шт 96 и 105, Bacillus sp., шт 25, выделенные из микробиоценоза льна, уступают в активности естественному комплексу микрофлоры. Оценена зависимость скорости биоразрушения льноволокон от содержания в них природных примесей, надмолекулярной структуры целлюлозы и состава микрофлоры. Отмечено уменьшение на порядок констант скорости биодеструкции полисахаридов после удаления их низкомолекулярных фрагментов в процессах очистки волокон.

Ключевые слова: биодеструкция, микробные культуры, комплекс микрофлоры, природные примеси льноволокон, структурно модифицированная целлюлоза.
\end{abstract}

\section{Введение}

В настоящее время актуальна проблема производства широкого ассортимента льносодержащей «ЭКО» продукции технического назначения (тепло- и шумоизоляционных, гипоаллергенных изделий, экоутеплителей и т.д.), востребованных в строительной индустрии, автомобилестроении, различных отраслях промышленности и в быту. Однако имея низкую биологическую устойчивость, целлюлозные материалы подвержены деструкции при длительном контакте с микроорганизмами или при эксплуатации в условиях, благоприятных для развития последних. Решение проблемы обеспечения высокой степени защиты волокон льна от биоразрушения требует изучения механизма процессов, протекающих при их взаимодействии с микробными культурами.

В литературе приводятся многочисленные сведения о биодеградации древесины, лигнинсодержащих примесей [1-6] и в значительно меньшей степени - о биоразрушении растительных волокон [7-11]. Изучение механизма воздействия МК или их метаболитов (ферментов, органических кислот) непосредственно на волокна льна проводится в основном с целью регулирования процессов роста и развития расте-

Морыганов Павел Андреевич - младший научный сотрудник, кандидат технических наук, e-mail: poul.m@mail.ru

Галашина Валентина Николаевна - старший научный сотрудник, кандидат технических наук, e-mail: vng@isc-ras.ru

Кузнецов Олег Ювенальевич - профессор кафедры микробиологии и вирусологии, доктор биологических наук, e-mail: olegkuz58@yandex.ru ний, совершенствования технологических процессов получения тресты, подготовки льняной ровницы к мокрому прядению, отделки льносодержащих текстильных материалов. В перечне указанных исследований вопросам изменения волокон под действием присутствующей на них микрофлоры уделяется внимание лишь в технологии мацерации (мочки) паренхимных тканей льносо-

\footnotetext{
* Автор, с которым следует вести переписку.
} 
ломы. В большинстве же случаев изучают результаты превращений, происходящих в волокнах льна, при использовании промышленно выпускаемых ферментативных препаратов, получаемых от лучших продуцентов и характеризующихся относительным постоянством состава и активности.

Состав популяций МК, сорбирующихся на целлюлозных материалах, различается в экологогеографических зонах и зависит от климата, растительности, состава почвы, температуры, влажности, интенсивности облучения и т.д. Кроме того, в волокнах льна может присутствовать часть «эпифитной микрофлоры», развивающейся на растениях льна в процессе их роста. На стеблях льна насчитывают более 40 видов различных МК, в том числе микроскопических грибов: представителей родов пеницилл (Penicillium) и аспергилл (Aspergillus), а также кладоспор (Cladosporium), аэробных (эрвинии - род Erwinia, псевдомонады - род Pseudomonas, бациллы - род Bacillus) и анаэробных бактерий (клостридии - род Clostridium), актиномицетов [12]. Представляется необходимым выявить факторы, определяющие скорость процесса разрушения льноволокон под действием естественного комплекса микрофлоры, т.е. сообщества культур, остающихся в льноволокнах после их выделения из стеблей или сорбирующихся в процессе переработки и хранения волокнистых материалов.

Цель настоящей работы - изучение динамики биодеградации волокон льна в зависимости от содержания в них природных примесей, надмолекулярной структуры целлюлозы и состава микрофлоры.

\section{Экспериментальная часть}

В качестве объектов исследования использовали нативные (не подвергавшиеся действию химических реагентов) волокна трех селекционных сортов льна-долгунца Мерилин, Росинка и Эскалина, предоставленные сотрудниками Всероссийского НИИ льна (г. Торжок). Вследствие высокой неоднородности льноволокон, трудоемкости экспериментального определения их характеристик и физико-механических показателей в качестве объектов использовали также льняную пряжу сухого и мокрого способов прядения линейной плотностью соответственно 222 и 121 текс. В последнем случае процессу прядения предшествовала стадия химического облагораживания льняной ровницы [13].

Для целенаправленного изменения состава природных примесей льняную пряжу 222 текс обрабатывали в соответствии с традиционными регламентами отварки и беления [13, с. 66-71], температурновременные параметры которых приведены в таблице 1. В двухфазной технологии беления обработке пероксидсодержащим раствором предшествовали операции щелочной варки и кислования. Изменение надмолекулярной структуры целлюлозы и перевод ее кристаллических областей из структурной модификации целлюлоза I (Целл. I) в целлюлозу II (Целл. II) обеспечивали мерсеризацией - обработкой пряжи 5 N раствором гидроксида натрия с последующим ее выдерживанием при комнатной температуре в течение 5 мин. После промывок пряжу высушивали при $30{ }^{\circ} \mathrm{C}$.

Культивирование микрофлоры на исследуемых объектах обеспечивали выдерживанием их в термостате ТС-80-2M при $29 \pm 0,2{ }^{\circ} \mathrm{C}$ и влажности 98-100\% в течение 28-56 суток. Отбор образцов на анализ осуществляли с интервалом 7-14 суток.

Вследствие многообразия естественного комплекса микрофлоры сложно априори выбрать МК, для которых условия существования на льноволокнах наиболее соответствуют их потребностям и которые являются конкурентоспособными в процессах захвата и освоения данного субстрата. Поэтому активно развивающиеся культуры выявляли эмпирически после создания условий для развития микрофлоры и появления на поверхности льноволокон скоплений окрашенных спор, грубых объемных образований, паутинообразных пленок. Подготовку индивидуальных культур к испытаниям проводили путем перенесения МК с колонизованной поверхности волокон на питательную среду в чашки Петри (для грибов - среда Сабуро, для бактерий - мясо-пептонный агар) и их последующего культивирования. [14]. Из состава микробиоценоза льна выделяли чистые культуры, которые оценивали по морфологическим и биохимическим признакам и сравнивали с тест-культурами из музея кафедры микробиологии и вирусологии ИвГМА. Для получения искусственной ассоциации грибковых и бактериальных культур выполняли смыв данных культур с поверхности агаризованной питательной среды стерильным физиологическим раствором, а затем смешивали их в эквивалентных количествах с соблюдением правил асептики.

В качестве индивидуальной культуры использовали также музейный штамм плесневого гриба $A s$ pergillus niger van Tieghem., включенный в перечень культур для испытаний целлюлозных материалов на грибостойкость по ГОСТ 9.802. Заражение биодеструкторами предварительно стерилизованных исследуемых объектов осуществляли путем пропитки последних в смывах, полученных перенесением в физиологический раствор МК. При культивировании естественного комплекса микрофлоры образцы не подвергали предварительной стерилизации и последующему искусственному заражению. 
Таблица 1. Условия химической обработки льняной пряжи сухого способа прядения

\begin{tabular}{l|c|c|c}
\hline \multicolumn{1}{c|}{ Операция } & Температура & \multicolumn{2}{|c}{ Длительность, мин } \\
\cline { 3 - 4 } & обработки, ${ }^{\circ} \mathrm{C}$ & нагрева & обработки \\
\hline Щелочная варка* & 92 & 30 & 60 \\
Кислование & 30 & 5 & 15 \\
Обработка пероксидсодержащим раствором* & 98 & 50 & 60 \\
Мерсеризация & 22 & - & 5 \\
\hline
\end{tabular}

Примечание. * концентрация основных реагентов в варочном и пероксидсодержащем растворах составляла, моль/л: гидроксида натрия - 0,15 и 0,11 соответственно; пероксида водорода (в пересчете на активный кислород) - 0,12.

Количественно процесс разрушения волокон оценивали по потере их массы, изменению содержания целлюлозы, природных примесей - компонентов лигноуглеводного комплекса (ЛУК), карбоксильных групп и физико-механических показателей. Содержание целлюлозы (ЦЛ), кислотонерастворимого лигнина (ЛГ) определяли гидролизно-объемным и сернокислотным методами; содержание карбоксильных групп (КГ) - кальций-ацетатным методом $[13,15,16]$. Пектиновые вещества (ПВ) и гемицеллюлозы (ГЦ) контролировали традиционными методами, соответственно, объемно-аналитическим и объемным Вильштеттера и Шудля $[15,16]$. В двух параллельных экспериментах абсолютная погрешность определений целлюлозы и лигнина составляла $\pm 0,1 \%, К Г- \pm 0,01 \%$, пектиновых веществ и гемицеллюлоз - $\pm 0,02 \%$.

Константу скорости биоразрушения $\left(K_{\text {бр }}\right.$.) ПВ и ГЦ микробными культурами на начальной стадии процесса определяли графически по тангенсу угла наклона полулогарифмических анаморфорз соответствующих кинетических кривых. Линейный характер зависимости $\ln C_{0} / C_{i}$ от длительности процесса указывал на первый порядок реакций.

Показатели, характеризующие размеры технических волокон, рассчитывали согласно [17]. В наблюдаемом интервале длин от 1 до 400 мм массовое содержание и количество близких по размерам волокон определяли после их ручного разбора на группы, отличающиеся на 20 мм.

Среднюю массодлину волокон $\left(\mathrm{L}_{д}\right)$ рассчитывали по формуле

$$
L_{\text {Д }}=\frac{\sum\left(L_{1} M_{1}+L_{2} M_{2}+\ldots+L_{i} M_{i}\right)}{\sum\left(M_{1}+M_{2}+\ldots+M_{i}\right)}=\frac{\sum(L M)}{\sum M}(\mathrm{MM}),
$$

где $\mathrm{L}_{1} \mathrm{~L}_{2} \ldots \mathrm{L}_{\mathrm{i}}-$ средняя длина волокон в группе, мм; $\mathrm{M}_{1} \mathrm{M}_{2} \ldots \mathrm{M}_{\mathrm{i}}-$ масса волокон в каждой группе, г.

Среднюю линейную плотность волокон ( $\mathrm{T}_{\text {ср. }}$ ) рассчитывали по следующей формуле:

$$
T_{c p .}=\left[\Pi_{1} \frac{M_{n 1}}{L_{1} n_{1}} \times 10^{6}+\Pi_{2} \frac{M_{n 2}}{L_{2} n_{2}} \times 10^{6}+\ldots+\Pi_{i} \frac{M_{n i}}{L_{i} n_{i}} \times 10^{6}\right] / 100 \text { (текс), }
$$

где $\mathrm{n}_{1}, \mathrm{n}_{2} \ldots \mathrm{n}_{\mathrm{i}}$ - количество волокон в группе, шт.; $\mathrm{M}_{\mathrm{n} 1}, \mathrm{M}_{\mathrm{n} 2} \ldots \mathrm{M}_{\mathrm{ni}}$ - масса $\mathrm{n}$ волокон в каждой группе, г; П процентное содержание волокон каждой группы, \%.

Изменение разрывных нагрузок нативных волокон после воздействия МК оценивали по заранее отобранным (до контакта с микрофлорой) волокнам длиной $150 \pm 10$ мм. При зажимной длине 80 мм данный показатель зависит, прежде всего, от степени скрепления элементарных волокон срединными пластинами, т.е. от состояния ЛУК. Разрывные нагрузки одиночных льноволокон и пряжи определяли соответственно на разрывных машинах FM-27 и РM-30-1. Для каждого образца рассчитывали среднее значение из 50 определений.

\section{Обсуждение результатов}

Различие в биоустойчивости целлюлозных материалов связывают с отличием в их структуре и в составе примесей. Последние могут выступать питательной средой для микробных культур. Отмечают, что биодеградация хлопка, древесины начинается с утилизации легкогидролизуемых полисахаридов [18], поэтому высокое содержание пектинов и гемицеллюлоз в льноволокне способствует росту его повреждаемости микроорганизмами. Напротив, нецеллюлозные примеси (лигнин, воскообразные вещества, флавоноиды) повышают его микробиологическую устойчивость [19]. Повышению биоустойчивости способствует также наличие в волокнах льна значительного количества микроэлементов (до 38 наименований), в том числе тяжелых и редкоземельных металлов: меди, цинка, марганца, свинца и др. [20]. 
Данные, представленные в таблице 2, позволяют сопоставить характер биоповреждений волокон льна трех селекционных сортов. Проведенный нами предварительный анализ показал, что данные волокна имели незначительные различия в цвете, геометрических параметрах, прочностных показателях и содер-

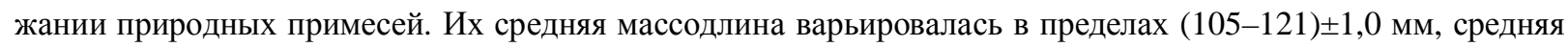

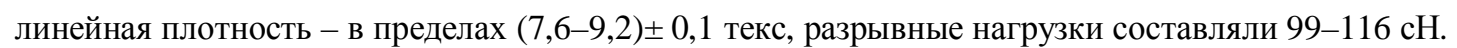

Количественные данные, характеризующие массовую долю целлюлозы в образце $\left(\mathrm{W}_{\text {обр.(i) }}\right)$, противоположным образом изменяются за счет ее биодеструкции и уменьшения содержания примесей. Поэтому масса целлюлозы ( $m_{\text {иел. }}$ ) была пересчитана на основании соотношения:

$$
m_{\text {чел. }}=\frac{m_{i} \cdot W_{\text {обр }(i)}}{100}(\text { мг })
$$

где $m_{i}$ - масса образца, рассчитанная с учетом потери массы волокон $\Delta m_{i}$, мг.

Аналогично пересчитано содержание примесей с учетом уменьшения массы образцов после воздействия биодеструкторов.

Согласно данным таблицы 2, развитие МК в течение первых двух недель приводит к потере 18,2$18,8 \%$ массы волокон и резкому снижению разрывных нагрузок волокон на 57-71\%. За этот период содержание целлюлозы и контролируемых полисахаридов уменьшается, соответственно, на 1050-1200 мг (столб. 8) и 500-800 мг (столб. 12). В течение последующих 2 недель дополнительная существенная утилизация целлюлозы на 502 и 250 мг при сравнительно небольшом увеличении конверсии полисахаридов на 20 и 90 мг вызывает значительно меньший прирост в потере прочности волокон. В этих случаях разрывные нагрузки дополнительно уменьшаются лишь на 13 и 4\% (у волокон Мерилин и Эскалина). По-видимому, резкое уменьшение разрывных нагрузок волокон на начальной стадии воздействия МК в значительной мере обусловлено интенсивным разрушением компонентов клеящего ЛУК (ПВ и ГЦ на 42-52\%). Возможность ослабления межволоконных связей и снижения прочности льноволокон именно за счет частичного удаления примесей реализуется в известных технологиях подготовки льняной ровницы к мокрому прядению [21].

Снижение доли контролируемых примесей в общей потере массы волокон (ср. столб. 4 и 5, табл. 2), наблюдаемое при длительном культивировании МК, указывает на возрастание биодеструкции целлюлозы. Согласно данным рентгеноструктурного анализа, воздействие на льноволокна естественного комплекса микрофлоры в течение 4 недель приводит к разрушению не только доступных аморфных областей, но и упорядоченных кристаллитных зон [22].

Следствием разрушения технических волокон является их распад на множество мелких фрагментов, отдельных коротких комплексов и элементарных волокон. Приведенные в таблице 2 близкие значения количественных данных, характеризующих изменение свойств волокон Мерилин, Росинка, Эскалина и констант скорости деструкции полисахаридов $\left(3,0 \cdot 10^{-5}-4,5 \cdot 10^{-5}\right.$ мин $\left.^{-1}\right)$, свидетельствуют о сопоставимости превращений исследуемых селекционных сортов льна при их биодеградации.

Следует отметить наблюдаемую в данных условиях неполную, не более чем на 59 и $63 \%$ биоконверсию полисахаридов. Наиболее вероятными причинами наличия трудноудаляемой части пектиновых веществ $(2,5-3,1 \%)$ и гемицеллюлоз (3,7-4,9\%), по-видимому, наряду с их низкой доступностью для реагентов, можно считать ограниченный набор ферментов, вырабатываемых МК, и защитное действие лигнина. Согласно литературным данным, глубокое биокатализируемое разрушение пектинов до остаточного содержания 0,2-0,3\%, например, при подготовке ровницы к мокрому прядению, обеспечивается мультиэнзимными ферментными комплексами (МЭК), содержащими ферменты как с полигалактуразной активностью (ПГ), так и пектинэстеразы (ПЭ) [23]. Аналогично в ферментативных способах мацерации стеблей льна эффективность выделения волокнистых пучков возрастает при включении в состав мацерирующих препаратов наряду с ПГ и ферментов, действующих на метоксилированные формы пектинов [24]. Возможной причиной устойчивости полисахаридов является и наличие белкового ингибитора полигалактуроназы, с которым связывают стойкость растений к грибным болезням и который действует на ПГ грибов, препятствуя их внедрению в волокна [25]. 
Таблица 2. Изменение состава и свойств нативных волокон льна под воздействием естественного комплекса микрофлоры

\begin{tabular}{|c|c|c|c|c|c|c|c|c|c|c|c|c|c|}
\hline \multirow{3}{*}{$\begin{array}{c}\text { Льняное во- } \\
\text { локно селекци- } \\
\text { онных сортов }\end{array}$} & \multirow{3}{*}{$\begin{array}{c}\text { Время } \\
\text { воздей- } \\
\text { ствия, } \\
\text { недель }\end{array}$} & \multirow{3}{*}{$\begin{array}{c}\text { Снижение раз- } \\
\text { рывных нагру- } \\
\text { зок, \% }\end{array}$} & \multicolumn{2}{|c|}{$\begin{array}{c}\text { Потеря массы } \\
\text { волокон } \Delta m_{i}, \%\end{array}$} & \multirow{3}{*}{$\begin{array}{c}\text { Содержание } \\
\text { целлюлозы } \\
\text { W обр.(i) } \%\end{array}$} & \multicolumn{6}{|c|}{ Содержание целлюлозы и примесей (мг)* в льноволокнах } & \multicolumn{2}{|c|}{$\kappa_{б р} \cdot 10^{5}$, мин $^{-1}$} \\
\hline & & & \multirow{2}{*}{ общая } & \multirow{2}{*}{$\begin{array}{c}\text { за счет } \\
\text { примесей }\end{array}$} & & \multirow{2}{*}{$\begin{array}{c}\text { массой } \\
m_{i}, \mathrm{M \Gamma}\end{array}$} & \multirow{2}{*}{ ЦЛ } & \multicolumn{4}{|c|}{ примесей } & \multirow{2}{*}{$\Pi B$} & \multirow{2}{*}{ ГЦ } \\
\hline & & & & & & & & ПВ & ГЦ & ЛГ & общее & & \\
\hline \multirow{4}{*}{ Мерилин } & 0 & - & - & - & 72,6 & 10000 & 7260 & 650 & 920 & 1180 & 2750 & 4,1 & 4,5 \\
\hline & 2 & 57,6 & 18,4 & 8,0 & 76,1 & 8160 & 6209 & 340 & 480 & 1130 & 1950 & & \\
\hline & 4 & 70,7 & 23,6 & 8,5 & 74,7 & 7640 & 5707 & 320 & 480 & 1100 & 1900 & & \\
\hline & 8 & 83,8 & 24,2 & 8,8 & 74,6 & 7580 & 5654 & 310 & 460 & 1100 & 1870 & & \\
\hline \multirow[t]{4}{*}{ Росинка } & 0 & - & - & - & 73,4 & 10000 & 7340 & 680 & 910 & 1060 & 2650 & 4,3 & 4,0 \\
\hline & 2 & 61 & 18,8 & 8,1 & 76,8 & 8120 & 6236 & 330 & 430 & 1080 & 1840 & & \\
\hline & 4 & 70,4 & 19,5 & 8,3 & 77,1 & 8050 & 6206 & 340 & 420 & 1060 & 1820 & & \\
\hline & 8 & 85,3 & 27,9 & 11,0 & 78,9 & 7210 & 5688 & 250 & 370 & 930 & 1550 & & \\
\hline \multirow[t]{3}{*}{ Эскалина } & 0 & - & - & - & 73,2 & 10000 & 7320 & 550 & 890 & 1160 & 2600 & 3,0 & 3,8 \\
\hline & 2 & 71,0 & 18,2 & 5,1 & 74,6 & 8180 & 6102 & 320 & 510 & 1260 & 2090 & & \\
\hline & 4 & 75,0 & 20,7 & 6,0 & 73,8 & 7930 & 5852 & 250 & 490 & 1260 & 2000 & & \\
\hline
\end{tabular}

*Содержание целлюлозы и примесей пересчитано с учетом потери массы волокна. 
Лигнинсодержащие примеси льна устойчивы к действию развивающейся микрофлоры (столб. 11, табл. 2). Степень разрушения лигнина не превышает $12 \%$, наблюдаемое же в ряде случаев увеличение его содержания может быть следствием протекания процессов полимеризации и конденсации. Обоснованность такого предположения подтверждается приводимыми в литературе сведениями, во-первых, о вероятности полимеризации лигнина при катализе ферментами и, во-вторых, о повышении массового содержания лигнина в льноволокнах вследствие его конденсации [26-29]. Отмечают, что полимеризация лигнина, катализируемая лакказой, может происходить за счет связывания реакционноспособных гваяцильных единиц, а деполимеризация установлена для сирингильных структур. В отличие от лакказы лигниназа характеризуется как ключевой лигнинразрушающий фермент, но и она способна катализировать полимеризационные процессы [6, 27, 28]. Эта особенность реализуется при окислении субстратов, содержащих свободный фенольный гидроксил.

Интересно оценить, в какой мере изменение структуры целлюлозы и начального содержания примесей влияет на динамику биоразрушения волокон льна. Согласно данным, приведенным на рисунке 1, химическими обработками льняной пряжи начальное содержание пектиновых веществ было уменьшено от 4,5 до 0,9\%, гемицеллюлоз - от 16 до 10,1\%. Это существенно изменило уровень их биоконверсии. Ход кинетических кривых 1-4 (рис. 1а) свидетельствует, что наиболее активная деструкция полисахаридов наблюдается в течение первой недели культивирования МК. Но если за этот период разрушение ПВ и ГЦ в нативных волокнах составляет 55 и 30\% (крив. 1), в мерсеризованных - 65 и 35\% (крив. 4), то в отваренных и отбеленных - лишь 40 и 4\%, 10 и 12\% (крив. 2, 3). Более динамичное снижение содержания гемицеллюлоз в отбеленных волокнах в сравнении с отваренными, по-видимому, обусловлено некоторым уменьшением их степени полимеризации при обработке пряжи пероксидсодержащим раствором (0,12 моль/л в пересчете на активный кислород).

Вполне логичной представляется более высокая устойчивость полисахаридов к биоразрушению после удаления их низкомолекулярных фрагментов в процессах очистки волокон. Приведенные в таблице 3 данные по уменьшению констант скорости биодеструкции ПВ и ГЦ на порядок и более, соответственно, от $6,5 \cdot 10^{-5}$ и $2,5 \cdot 10^{-5}$ до $0,02 \cdot 10^{-5}$ и $0,4 \cdot 10^{-5}$ мин $^{-1}$ свидетельствуют о значительном замедлении процесса их разрушения в отваренной и отбеленной пряже. Напротив, частичная деструкция примесей при кратковременном воздействии концентрированного щелочного раствора, увеличивающая содержание низкомолекулярных фрагментов, приводит к ускоренному разрушению ПВ и ГЦ в мерсеризованной пряже и росту соответствующих констант в 1,1-1,2 раза.

Повышение биоустойчивости очищенных волокон убедительно подтверждается данными об изменении разрывных нагрузок пряжи, представленными на рисунке 2. Согласно кривым 2, 3 при культивировании МК в течение 4 недель потери прочности отваренной и отбеленной пряжи не превышают $20 \%$, в то время как у суровой они составляют 60,3\% (кривая 1), а у мерсеризованной - $100 \%$ (кривая 4). Однако в течение следующих 4 недель разрушение очищенных волокон ускоряется и к концу этого периода потери их прочности достигают 63-80\%.

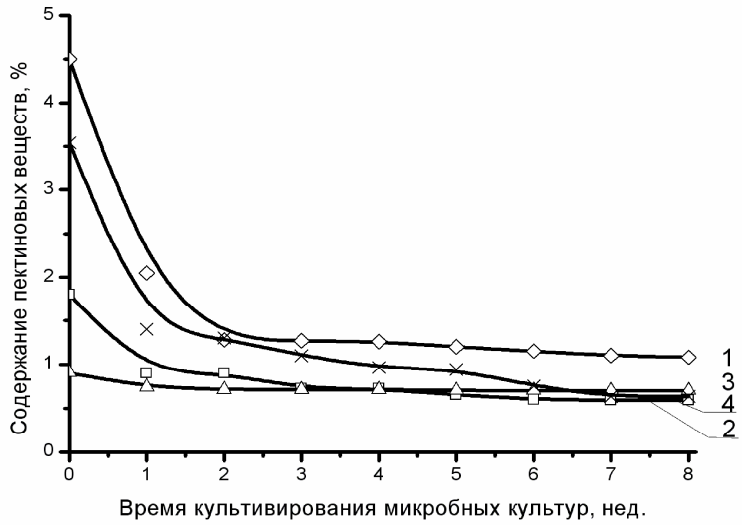

a

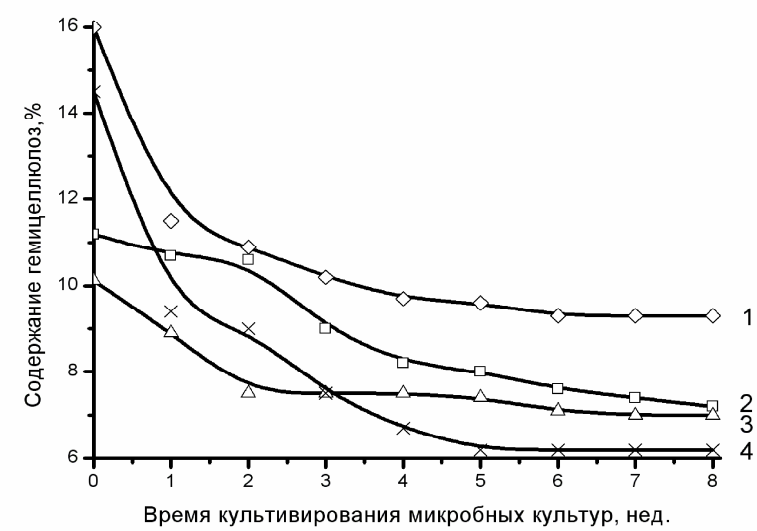

6

Рис. 1. Динамика разрушения пектиновых веществ (а) и гемицеллюлоз (б) в льняной пряже различной степени очистки (номера кривых соответствуют номерам образцов в табл. 3) 
Таблица 3. Скорость биодеструкции полисахаридов в льняной пряже различной степени очистки

\begin{tabular}{l|c|c|c|c}
\hline \multicolumn{2}{c}{ Образцы льняной пряжи } & Структурная модифи- & Разрывная & \multicolumn{2}{|c}{$\mathrm{K}_{\text {бр }} \cdot 10^{5}$, мин $^{-1}$} \\
\cline { 4 - 5 } & кация целлюлозы & нагрузка, H & ПВ & ГЦ \\
\hline 1. Суровая & Ц I & 31,5 & 6,5 & 2,5 \\
2. Отваренная & Ц I & 27,4 & 5,0 & 0,4 \\
3. Отбеленная & Ц I & 23,8 & 0,02 & 1,2 \\
4. Мерсеризованная & Ц II & 29,8 & 7,2 & 3,1 \\
\hline
\end{tabular}

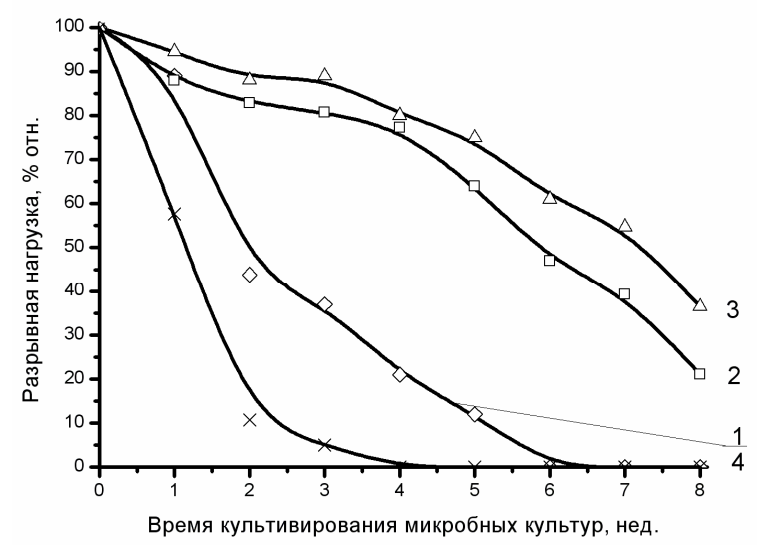

Рис. 2. Изменение прочностных показателей льняной пряжи (номера кривых соответствуют номерам образцов в табл. 3)

Независимо от начального содержания примесей при длительном культивировании МК на льняной пряже наблюдается несоответствие между уменьшением деструкции примесей (рис. 1) и ростом потери массы волокон $\Delta m_{i}$ (рис. 3а), свидетельствующее о возрастании биоразрушения целлюлозы. Динамику изменения массового содержания целлюлозы $\left(\Delta m_{\text {цел. }}\right)$ определяли по разнице потери массы волокон $\Delta m_{i}$ и убыли контролируемых примесей (ПВ, ГЦ, ЛГ):

$$
\Delta m_{\text {иел.i }}=\Delta m_{i}-\left(m_{П в 0}-m_{П В і}\right)-\left(m_{Г Ц 0}-m_{Г Ц і}\right)-\left(m_{Л Г 0}-m_{Л Г i}\right)(\%),
$$

где $m_{П в 0}, m_{Г Ц 0}, m_{Л Г 0}$ - начальное содержание ПВ, ГЦ и ЛГ в пряже, $\% ; m_{П В і}, m_{\Gamma Ц i}, m_{Л Г i}-$ содержание ПВ, ГЦ и ЛГ в пряже после і недель культивирования естественного комплекса микрофлоры, \%.

Уменьшение массы воскообразных, зольных, минеральных примесей в общей потере массы волокон не учитывали вследствие их меньшей подверженности воздействию микробных культур [9, 30].

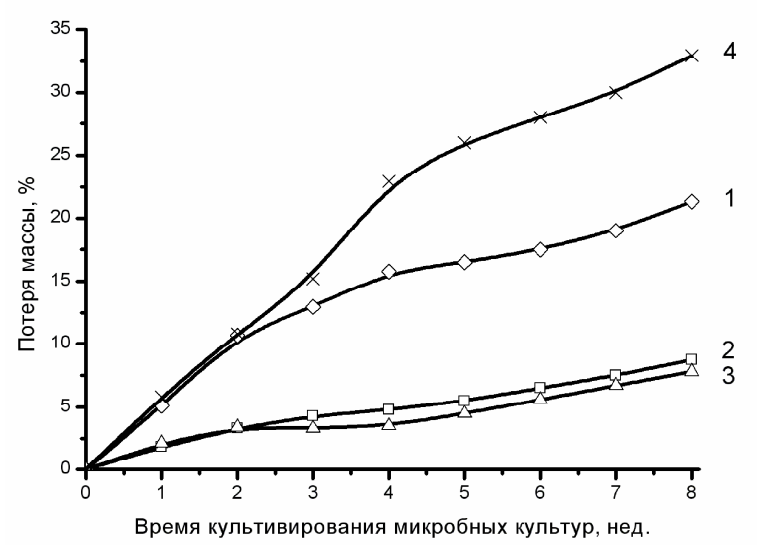

a

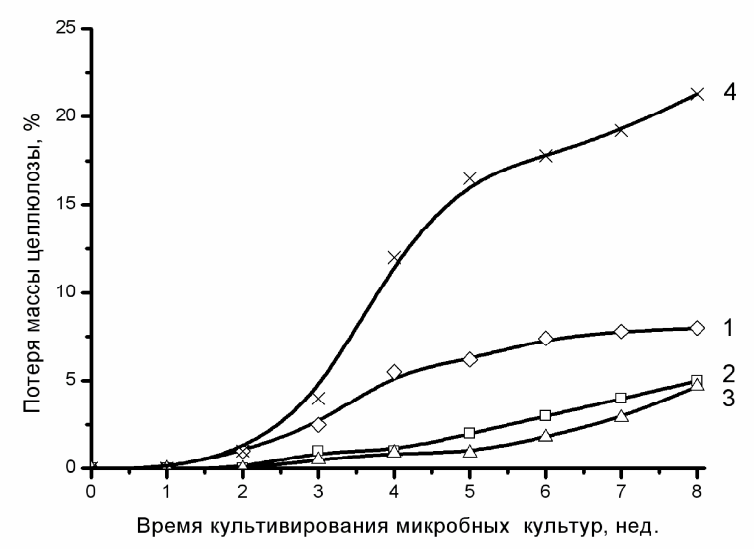

6

Рис. 3. Потеря массы волокон $\Delta m_{i}$ (а) и целлюлозы $\Delta m_{\text {иел.і }}$ (б) в процессе биоразрушения льняной пряжи (номера кривых соответствуют номерам образцов в табл. 3) 
Представленные на рисунке $3 б$ данные свидетельствуют, что в течение восьми недель потеря массы целлюлозы в волокнах очищенных (крив. 2, 3) не превышает 5\%. Значительный рост разрушения целлюлозы в пряже мерсеризованной $(21 \%)$ по сравнению с суровой $(8 \%)$ наблюдается при сопоставимой $(11,4$ и 10,2\%) биоконверсии полисахаридов (рис. 1) и меньшей биодеградации лигнина (табл. 4). Это указывает на важное значение увеличения аморфных зон целлюлозы в ее разрушении микроорганизмами. Низкая устойчивость льноволокон со структурно модифицированной целлюлозой к воздействию естественного комплекса микрофлоры ранее была доказана результатами рентгеноструктурного анализа [21].

Короткие индукционные периоды на кинетических кривых 1 и 4, по-видимому, обусловлены ускоренным развитием микроорганизмов, выделяющих целлюлолитические ферменты. Так, если продуцирование целлюлаз микробными культурами, развивающимися на пряже отваренной и отбеленной, начинается после четырех-пяти недель их культивирования, то на пряже суровой и мерсеризованной - уже после одной-двух недель.

Данные таблицы 4 показывают, что после 8 недель культивирования МК содержание природного лигнина (химически не измененного) снижается не более чем на $30 \%$ (столб. 2), видоизмененного предварительными химическими обработками (столб. 3-5) - на 6,5-9\%. Однако в некоторых случаях его содержание остается неизменным либо увеличивается. По-видимому, в сложном, многофакторном процессе биодеградации лигнина льна, МК в зависимости от условий и сроков их культивирования могут инициировать как протекание реакций разрушения структуры лигнина, так и реакций его полимеризации и конденсации.

Известно, что лигнин экранирует целлюлозу и сопутствующие примеси и, затрудняя набухание, делает их более устойчивыми к ферментативному гидролизу. Однако анализ совокупности данных, приведенных в таблице 4 и на рисунках 1-3, свидетельствует об отсутствии корреляции между уменьшением содержания лигнина в льноматериалах и изменением биоразрушения льноволокон. Так, согласно кинетическим кривым рисунка 2, меньшие разрывные нагрузки имеет суровая пряжа (крив. 1) в сравнении с пряжей отваренной и отбеленной (крив. 2 и 3), несмотря на более высокое содержание в ней лигнина (13,9 против 12,4 и 8,4\%, табл. 4). Следовательно, пространственное экранирование целлюлозы лигнином не является определяющим фактором в динамике биоразрушения целлюлозы льна и ее природных спутников и возможное защитное действие лигнина не проявляется в явном виде.

Внешний вид льноволокон после культивирования на них естественного комплекса микрофлоры в течение двух недель представлен на рисунке 4. Фотографии наглядно свидетельствуют о развитии МК преимущественно на нативных волокнах и волокнах со структурно модифицированной целлюлозой, что подтверждает зависимость процесса биоразрушения от структуры целлюлозы льна и содержания ее природных спутников.

Анализом изменения прочности льняной пряжи после воздействии химических реагентов (табл. 3) выявлено незначительное снижение ее разрывных нагрузок (на 13-24\%) в условиях обработки щелочными и перксидсодержащими растворами, обеспечивающими удаление из волокон 60 и 85\% ПВ, 30 и $36 \%$ ГЦ (рис. 1). Возможной причиной более значительной потери прочности материала при аналогичной степени биоразрушения контролируемых примесей является его механическое повреждение микроорганизмами, например, разрастающимся мицелием грибов, проникающим в поры, трещины и увеличивающим в волокнах количество дефектных мест.

Таблица 4. Деструкция лигнина в льняной пряже различной степени очистки

\begin{tabular}{c|c|c|c|c}
\hline Время культивирования & \multicolumn{3}{|c}{ Содержание лигнина (\%) в пряже*: } \\
\cline { 2 - 5 } МК, нед. & суровой & отваренной & отбеленной & мерсеризованной \\
\hline 0 & 13,9 & 12,4 & 8,4 & 13,8 \\
1 & 13,1 & 12,6 & 8,2 & 14,4 \\
2 & 12,1 & 12,6 & 8,2 & 12,1 \\
3 & 12,0 & 11,3 & 8,2 & 11,9 \\
4 & 12,0 & 12,2 & 8,6 & 12,4 \\
8 & 9,7 & 11,6 & 8,5 & 12,5 \\
\hline
\end{tabular}

\footnotetext{
* Содержание примесей рассчитано с учетом потери массы волокна.
} 
Нативное волокно

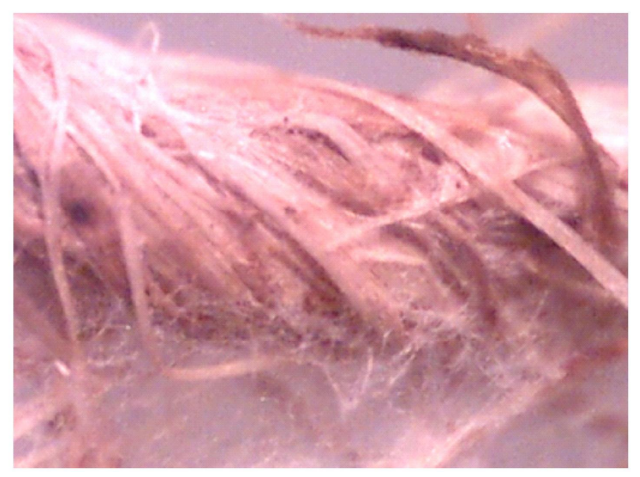

Отбеленное волокно

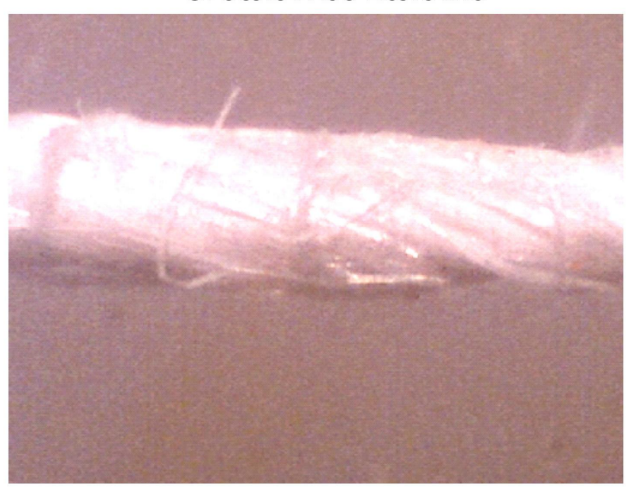

Отваренное волокно

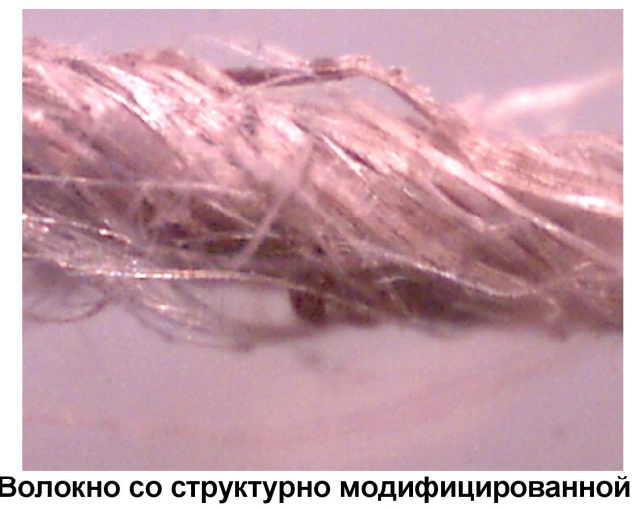

целлюлозой

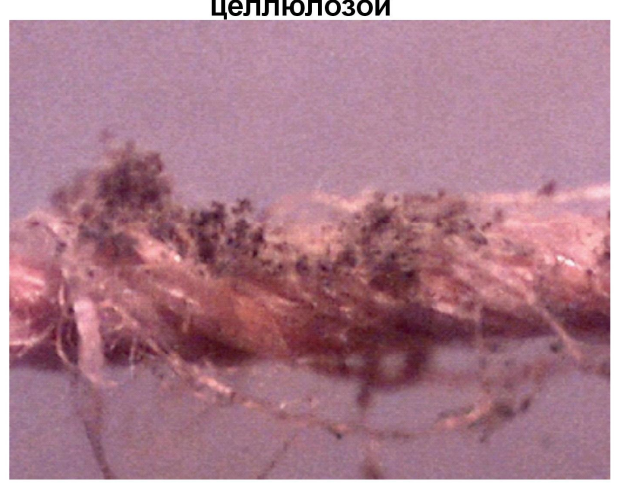

Рис. 4. Внешний вид льняной пряжи различной степени очистки после культивирования естественного комплекса микрофлоры в течение 2 недель (увеличение ×60)

Зависимость активности каталитического действия лигнолитических ферментов от присутствия кислорода позволила доказать, что деструкция лигнина является окислительным процессом. Кинетические кривые изменения прочностных показателей и содержания карбоксильных групп, приведенные на рисунках 5 и 6, позволяют сопоставить результаты воздействия на волокна льна адаптированных к ним микробных культур и штамма гриба Aspergillus niger, неспособного вызывать окислительные изменения в лигнине [31]. Для исключения убыли КГ за счет разрушения карбоксилсодержащих примесей, в данном эксперименте использовали пряжу мокрого способа прядения с содержанием пектиновых соединений 0,22\%, гемицеллюлоз $-7,6 \%$ и лигнина $-7,5 \%$.

Кинетические кривые на рисунке 5а характеризуют разрушение льноволокон индивидуальными микробными культурами (кривые 1-3), искусственно созданной на их основе ассоциацией (кривая 4) и естественным комплексом микрофлоры (кривая 5). Из приведенных данных следует, что грибы рода Репicillum, проявляют более высокую активность в разрушении волокнистого субстрата в сравнении с бактериальной культурой рода Bacillus. Вместе с тем возможности индивидуальных МК ограничены и при их воздействии в течение 4 недель снижение разрывных нагрузок пряжи не превышает 52\%, что свидетельствует о недостаточно высокой активности метаболитов, продуцируемых отдельными штаммами. Однако совместное действие трех указанных культур (крив. 4) вызывает снижение разрывной нагрузки лишь на $37 \%$. Это показывает, что создание искусственной ассоциации грибов и бактерий путем смешения их в эквивалентных количествах не обеспечивает совпадения ферментного набора, необходимого для нормального роста и развития экспериментального микробиоценоза.

Наблюдаемый в этом случае явно выраженный индукционный период свидетельствует о наличии антагонистических противоречий и о том, что выделяющиеся метаболиты и продукты разрушения примесей могут замедлять развитие МК и исключать на какое-то время их деструктирующее воздействие на полимер. Эффект антагонизма в созданной искусственной ассоциации культур, успешно развивающихся на волокне, явился неожиданным. Можно предположить, что одной из причин наличия противоречий у вышеуказанных МК является изменение метаболитов в процессе выделения индивидуальных культур и их культивирования на питательных средах (для грибов - среда Сабуро, для бактерий - мясо-пептонный агар). Приводятся сведения, что степень выраженности антагонистических свойств штаммов зависит от параметров культивирования, в частности, от состава питательной среды [32]. 


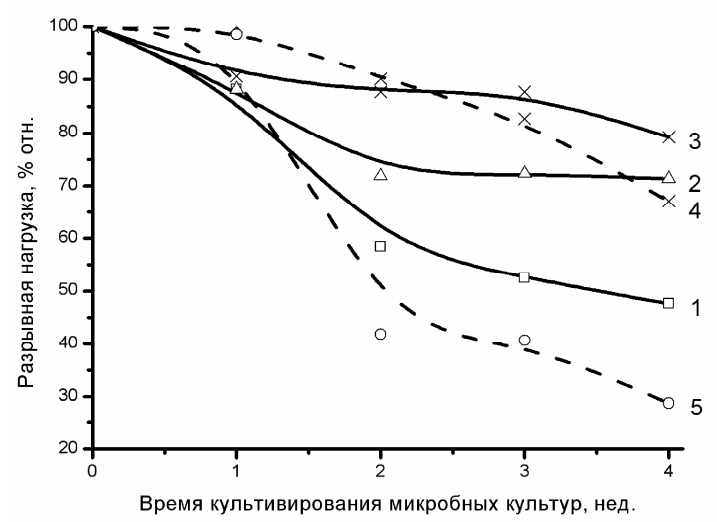

a

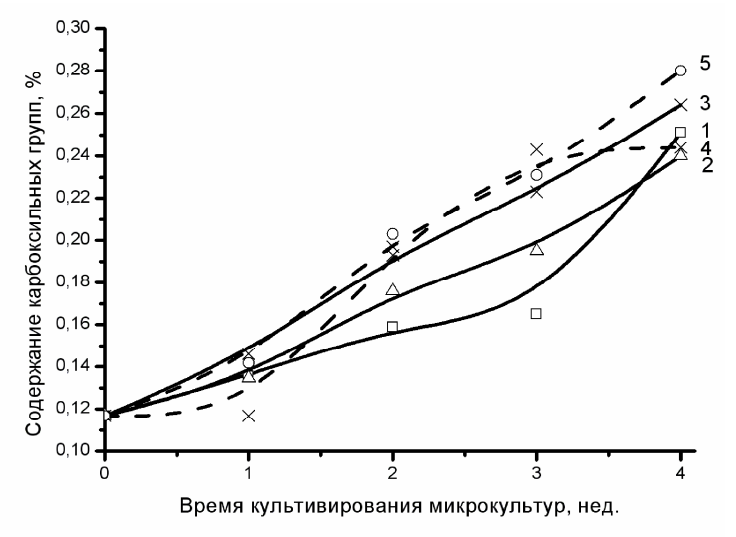

б

Рис. 5. Изменение прочностных показателей льняной пряжи (а) и содержания карбоксильных групп целлюлозы и ее спутников (б) при воздействии МК. 1 - Penicillum sp., шт. 96; 2 - Penicillum sp., шт. 105; 3 - Bacillus sp., шт. 25; 4 - Penicillum sp., шт 96 и 105, Bacillus sp., шт 25; 5 - естественный комплекс микрофлоры

Важно отметить, что при помещении исследуемого объекта, не прошедшего предварительную стадию стерилизации, и без специального заражения в условия, оптимальные для развития естественного комплекса микрофлоры, происходит более значительное разрушение материала и потеря прочности достигает $70 \%$ (кривая 5).

Согласно кинетическим кривым на рисунке 5б, следствием воздействия МК является увеличение содержания КГ в исследуемых объектах в 2,0-2,3 раза (от 0,12 до 0,24-0,28\%). При этом отсутствие корреляции между накоплением КГ и изменением показателей разрывных нагрузок пряжи, по-видимому, может быть обусловлено именно окислительными превращениями лигнина, которые не сопровождаются адекватным снижением прочности волокнистого материала.

Совершенно иной характер изменения карбоксильных групп и разрывных нагрузок пряжи наблюдается при воздействии на исследуемый объект штамма плесневого гриба Aspergillus niger, напомним, неспособного вызывать окислительные изменения в лигнине. Кривые 1 и 2 (рис. 6) изменяются антибатно и незначительному повышению содержания КГ (от 0,12 до 0,16\%) на протяжении 4 недель соответствует столь же незначительное снижение разрывных нагрузок. Однако в период резкого накопления КГ (кривая 2) наблюдается не менее резкое снижение прочности волокон после 5 недель воздействия биодеструктора (кривая 1).

Причиной снижения прочностных показателей льняной пряжи при воздействии гриба Aspergillus niger являются окислительные превращения в целлюлозе. В отсутствии продуктов окислительной деградации лигнина (фенольных радикалов, хинонов), способных инактивировать целлюлолитические ферменты, может возрастать деструкция целлюлозы. Наблюдаемое в этих условиях значительное накопление карбоксильных групп, по-видимому, является следствием окисления гидроксильных групп целлюлозы, сопровождающегося ее разрушением.

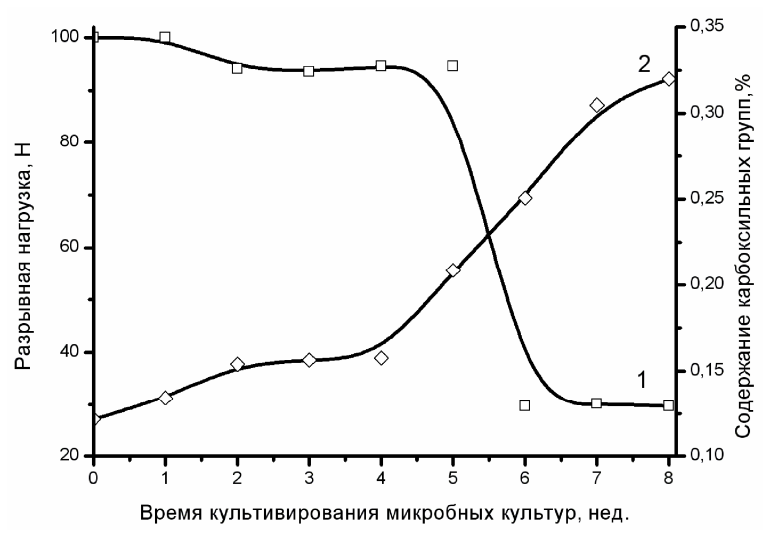

Рис. 6. Изменение разрывных нагрузок (1) и содержания карбоксильных групп (2) при воздействии на льняную пряжу штамма гриба Aspergillus niger 


\section{Заключение}

Таким образом, биодеструкция волокон льна в условиях, благоприятных для развития присутствующей на них микрофлоры (влажность $100 \%$ при $29 \pm 0,2{ }^{\circ} \mathrm{C}$ ), приводит в первые две-четыре недели к интенсивному разрушению легкогидролизуемой части полисахаридов и последующей прогрессирующей деструкции целлюлозы. Выявленное наличие трудноудаляемой части пектиновых веществ и гемицеллюлоз (соответственно 0,6-1,0 и 5,0-6,0\%), не извлеченных из волокон льна после их восьминедельной биодеградации, обусловлено низкой доступностью для реагентов части гемицеллюлоз и недостаточно активным комплексом ферментов, вырабатываемых МК. Чрезвычайно важно подчеркнуть, что наличие низкомолекулярных полисахаридов является фактором, интенсифицирующим разрушение целлюлозы льна. В волокнах с уменьшенным содержанием пектиновых соединений и гемицеллюлозы развитие МК, продуцирующих целлюлолитические ферменты, начинается на две-три недели позднее и количество биодеградируемой целлюлозы снижается не менее чем на $60 \%$.

\section{Список литературы}

1. Абрамович Ц.Л., Озолиня Н.Р., Сергеева В.Н. Изменение микроморфологической структуры и химического состава древесины березы в процессе поражения грибами белой гнили // Химия древесины. 1987. №2. С. 96-100.

2. Ауиньш Э.А. Деструкция некоторых технических целлюлоз и древесных волокон неселективными сообществами микроорганизмов в условиях залегания в водоемах // Химия древесины. 1982. №5. С. 94-100.

3. Каткевич Ю.Ю., Каткевич Р.Г. Целлюлолитические ферменты и их действие на древесную целлюлозу (обзор) // Химия древесины. 1979. №5. С. 9-22.

4. Иоелович М.Я., Озолиня Н.Р., Тупурейне А.Д. Структурные изменения компонентов древесины при воздействии грибов белой гнили // Химия древесины. 1989. №3. С. 96-100.

5. Головлева Л.А., Мальцева О.В., Мясоедова Н.М., Полманис А.Г., Эриньш П.П., Жуков Н.А. Оценка влияния различных способов предобработки растительных субстратов на лигнолитическую активность гриба PANUS TIGRINUS // Химия древесины. 1988. №2. С. 66-71.

6. Дьячкова С.Г., Медведева С.А., Бабкин В.А. Деструкция лигнина, выделенного из древесины осины и лиственницы, базидиомицетом CORIOLUS VILLOSUS // Химия древесины. 1994. №1. С. 26-35.

7. Илларионова К.В. Влияние биоповреждений на структуру и свойства природноокрашенного волокна новых селекционных линий хлопчатника : автореф. дисс. ... канд. техн. наук. СПб., 2007. 16 с.

8. Платонова Н.В., Клименко И.Б., Ковальчук Т.И. Влияние биодеструкции на структуру хлопкового волокна // Текстильная химия. 1993. №1 (3). С. 15-19.

9. Пивень Т.В., Ходырев В.И. Биодеструкция льна и хлопка // Химия древесины. 1988. №1. С. 100-105.

10. Пивень Т.В., Ходырев В.И. О влиянии спутников целлюлозы льна на его стойкость к микробиологическому разрушению // Химия древесины. 1988. №1. С. 106-111.

11. Бабицкая В.Г., Щерба В.В., Осадчая О.В., Латышева С.Г. Деградация лигнина соломы ржи и костры льна под действием мицелиальных грибов // Химия древесины. 1990. №6. С. 83-88.

12. Маламене Б.А. Микроорганизмы и лен. Минск, 2002. 45 с.

13. Справочник по химической обработке льняных тканей / под ред. Э.Р. Шелковской. М., 1973. 406 с.

14. Галашина В.Н., Морыганов П.А., Кузнецов О.Ю. Биозащита льносодержащих нетканых материалов технического назначения // Текстильная промышленность. Научный альманах. 2008. №4. С. 40-44.

15. Иванов А.Н., Гурусова А.А. Оценка качества льняных волокон на ранних этапах селекции физикохимическими методами: методические указания. М., 1988. 24 с.

16. Садов Ф.И., Соколова Н.М., Шиканова И.А., Корчагин М.В., Калинина К.Г. Лабораторный практикум по курсу химическая технология волокнистых материалов. М., 1955. 428 с.

17. Кукин Г.Н., Соловьев А.Н., Кобляков А.И. Текстильное материаловедение. М., 1989. С. 81-105.

18. Малышева О.Н., Меламед Ц.Э. Влияние дереворазрушающих грибов на содержание свободных углеводов в древесине березы // Химия древесины. 1976. №2. С. 105-107.

19. Живетин В.В., Гинзбург Л.Н., Ольшанская О.М. Лен и его комплексное использование. М., 2002. 394 с.

20. Ольшанская О.М., Котин В.В., Артемов А.В. Критерии оценки экологической чистоты льняной текстильной продукции // Журнал Российского химического общества им. Д.И. Менделеева. 2002. №2. С. 66-76.

21. Справочник. Прядение льна и химических волокон / под ред. Л.Б. Карякина, Л.Б. Гинзбурга. М., 1991. С. 319-320.

22. Морыганов П.А., Галашина В.Н., Завадский А.Е. Изучение биодеструкции волокон льна в присутствии наночастиц серебра // Журнал прикладной химии. 2010. Т. 83, вып. 9. С. 1517-1524.

23. Кокшаров С.А., Чистякова Г.В., Алеева С.В. Комплексное решение проблем повышения сохранности целллюлозы в процессах расщепления примесей текстильных материалов из природных волокон // Химия растворов и технология жидкофазных материалов. Достижения и перспективы. Иваново. 2006. С. 259-275.

24. Бравова Г.Б. Биосинтез пектолитических ферментов анаэробными бактериями рода Clostridium : дисс. ... канд. биол. наук. М., 1972. 182 с. 
25. Глинка Е.М., Буланцева Е.А., Салькова Е.Г., Проценко М.А. Влияние БИПГ на интенсивность образования олигоуронидов // Физиология растений. 2003. Т. 50, №2. С. 260-264.

26. Медведева С.А., Середкина С.Г., Хуторянский В.А. Изменение молекулярно-массовых характеристик лигнинов, выделенных из древесины осины, деструктированной грибом Phanerochaete Sanguinea // Химия древесины. 1991. №5. С. 61-67.

27. Медведева С.А., Середкина С.Г., Бабкин В.А. Механизм и реакции деструкции лигнина и моделирующих его ароматических соединений грибами белой гнили // Химия древесины. 1992. №2-3. С. 3-24.

28. Александрова Г.П. Микробиологическая деструкция лигнина - основа технологических процессов биоделигнификации : дисс. ... канд. хим. наук. Иркугск, 1994. 194 с.

29. Званский Б.В., Комарова И.В., Елкин В.В. Превращения высокомолекулярных нецеллюлозных компонентов льна при термической обработке // Химия древесины. 1983. №3. С. 108.

30. Соловьев В.А., Малышева О.Н., Малеева И.Л. Изменение химического состава древесины под действием лигнинразрушающих грибов // Химия древесины. 1985. №6. С. 94-100.

31. Каткевич Р.Г. Исследование ферментативного гидролиза гемицеллюлоз // Химия древесины. 1975. №2. С. 31-36.

32. Гринько О.М. Экспериментальное изучение антагонистических свойств штамма бактерий Bacillus pumilus «Пашков» : автореф. дисс. ...канд. мед. наук. М., 2010. 24 с.

Поступило в редакичию 18 сентября 2012 2.

После переработки 10 апреля 2015 г.

Moryganov P.A.*, Galashina V.N., Kuznetsov O.Yu. INFLUENCE BIODESTRUCTORS ON CELLULOSE AND NATURAL IMPURITY OF FLAX FIBERS IS STUDYING

${ }^{1}$ G.A. Krestov Institute of Solution Chemistry of the Russian academy of Sciences, Akademicheskaya St., 1. Ivanovo, 153045 (Russia)

${ }^{2}$ Ivanovo state medical academy of the Ministry of Health and Social Development, F. Engels Avenue, 8. Ivanovo, 153012 (Russia),e-mail:poul.m@mail.ru,vng@isc-ras.ru

Features of composition and structure of flax fibers as objects of influence of microbic cultures (MC) are investigated. Data on dynamics of change of the cellulose content and natural impurity accompanying it (pectine, hemicellulose, lignin) in the conditions of cultivation of individual MC and a natural complex of microflora are given. On the example of native flax fibers of selection grades Merlyn, Rosinka and Eskalina it is shown that decrease in their explosive loads of 57-71\% in the first two weeks of influence of MC, is considerably caused by intensive destruction of pectin and hemicelluloses for $42-52 \%$. It is revealed that the individual cultures of Penicillum sp. strain 96 and and, Bacillus sp., strain 25 allocated from a flax microbiocenosis concede in activity to a natural complex of microflora. Dependence of speed of biodestruction of flax fibers on the contents at them natural impurity, supramolecular structure of cellulose and composition structure is estimated. It is noted to reduction much of constants of speed of biodestruction of polysaccharides after removal of their low-molecular fragments in processes of finishing of fibers.

Keywords: biodestruction, microbic cultures, microflora complex, natural impurity of a flax fiber, structural modification of cellulose.

\footnotetext{
* Corresponding author.
} 


\section{References}

1. Abramovich Ts.L., Ozolinia N.R., Sergeeva V.N. Khimiia drevesiny, 1987, no. 2, pp. 96-100. (in Russ.).

2. Auin'sh E.A. Khimiia drevesiny, 1982, no. 5, pp. 94-100. (in Russ.).

3. Katkevich Iu.Iu., Katkevich R.G. Khimiia drevesiny, 1979, no. 5, pp. 9-22. (in Russ.).

4. Ioelovich M.Ia., Ozolinia N.R., Tupureine A.D. Khimiia drevesiny, 1989, no. 3, pp. 96-100. (in Russ.).

5. Golovleva L.A., Mal'tseva O.V., Miasoedova N.M., Polmanis A.G., Erin'sh P.P., Zhukov N.A. Khimiia drevesiny, 1988, no. 2, pp. 66-71. (in Russ.).

6. D'iachkova S.G., Medvedeva S.A., Babkin V.A. Khimiia drevesiny, 1994, no. 1, pp. 26-35. (in Russ.).

7. Illarionova K.V. Vliianie biopovrezhdenii na strukturu i svoistva prirodnookrashennogo volokna novykh selektsionnykh linii khlopchatnika : avtoref. dis. ... kand. tekhn. nauk. [Influence of biological damage to the structure and properties of natural colored fibers of new breeding lines of cotton: the Dissertation of the candidate of technical sciences]. Sankt-Petersburg, 2007, 16 p. (in Russ.).

8. Platonova N.V., Klimenko I.B., Koval'chuk T.I. Tekstil'naia khimiia, 1993, no. 1(3), pp. 15-19. (in Russ.).

9. Piven' T.V., Khodyrev V.I. Khimiia drevesiny, 1988, no. 1, pp. 100-105. (in Russ.).

10. Piven' T.V., Khodyrev V.I. Khimiia drevesiny, 1988, no. 1, pp. 106-111. (in Russ.).

11. Babitskaia V.G., Shcherba V.V., Osadchaia O.V., Latysheva S.G. Khimiia drevesiny, 1990, no. 6, pp. 83-88. (in Russ.).

12. Malamene B.A. Mikroorganizmy i len. [Microorganisms and linen]. Minsk, 2002, 45 p. (in Russ.).

13. Spravochnik po khimicheskoi obrabotke l'nianykh tkanei. [Guide to the chemical treatment of linen fabrics]. Ed. E.R. Shelkovskaia. Moscow, 1973, 406 p. (in Russ.).

14. Galashina V.N., Moryganov P.A., Kuznetsov O.Iu. Tekstil'naia promyshlennost'. Nauchnyi al'manakh, 2008, no. 4, pp. 40-44. (in Russ.).

15. Ivanov A.N., Gurusova A.A. Otsenka kachestva l'nianykh volokon na rannikh etapakh selektsii fiziko-khimicheskimi metodami. Metodicheskie ukazaniia. [Evaluation of the quality flax fibers in the early stages of selection of physical and chemical methods. Guidelines]. Moscow, 1988, 24 p. (in Russ.).

16. Sadov F.I., Sokolova N.M., Shikanova I.A., Korchagin M.V., Kalinina K.G. Laboratornyi praktikum po kursu khimicheskaia tekhnologiia voloknistykh materialov. [Laboratory workshop at the rate of chemical technology of fibrous materials]. Moscow, 1955, 428 p. (in Russ.).

17. Kukin G.N., Solov'ev A.N., Kobliakov A.I. Tekstil'noe materialovedenie. [Textile Materials]. Moscow, 1989, pp. 81-105. (in Russ.).

18. Malysheva O.N., Melamed Ts.E. Khimiia drevesiny, 1976, no. 2, pp. 105-107. (in Russ.).

19. Zhivetin V.V., Ginzburg L.N., Ol'shanskaia O.M. Len i ego kompleksnoe ispol'zovanie. [Len and comprehensive utilization]. Moscow, 2002, 394 p. (in Russ.).

20. Ol'shanskaia O.M., Kotin V.V., Artemov A.V. Zhurnal Rossiiskogo khimicheskogo obshchestva im. D.I. Mendeleeva, 2002, no. 2, pp. 66-76. (in Russ.).

21. Priadenie l'na i khimicheskikh volokon. Spravochnik. [Spinning of flax and chemical fibers. Directory]. Ed. L.B. Kariakin, L.B. Ginzburg. Moscow, 1991, pp. 319-320. (in Russ.).

22. Moryganov P.A., Galashina V.N., Zavadskii A.E. Zhurnal prikladnoi khimii, 2010, vol. 83, issue 9, pp. 1517-1524. (in Russ.).

23. Koksharov S.A., Chistiakova G.V., Aleeva S.V. Khimiia rastvorov i tekhnologiia zhidkofaznykh materialov. Dostizheniia i perspektivy. [Chemistry of solutions and technology of liquid-phase materials. Achievements and Prospects]. Ivanovo. 2006, pp. 259-275. (in Russ.).

24. Bravova G.B. Biosintez pektoliticheskikh fermentov anaerobnymi bakteriiami roda Clostridium : dis. ... kand. biol. nauk. [The biosynthesis of proteolytic enzymes anaerobic bacteria of the genus Clostridium: $\mathrm{PhD}$ dissertation]. Moscow, 1972. 182 p. (in Russ.).

25. Glinka E.M., Bulantseva E.A., Sal'kova E.G., Protsenko M.A. Fiziologiia rastenii, 2003, vol. 50, no. 2, pp. $260-264$. (in Russ.).

26. Medvedeva S.A., Seredkina S.G., Khutorianskii V.A. Khimiia drevesiny, 1991, no. 5, pp. 61-67. (in Russ.).

27. Medvedeva S.A., Seredkina S.G., Babkin V.A. Khimiia drevesiny, 1992, no. 2-3, pp. 3-24. (in Russ.).

28. Aleksandrova G.P. Mikrobiologicheskaia destruktsiia lignina-osnova tekhnologicheskikh protsessov biodelignifikatsii : dis. ... kand. khim. nauk. [Microbial degradation of the lignin-base bio delignification processes: the dissertation Cand. Chem. Sci.]. Irkutsk, 1994, 194 p. (in Russ.).

29. Zvanskii, B. V., Komarova I.V., Elkin V.V. Khimiia drevesiny, 1983, no. 3, p. 108. (in Russ.).

30. Solov'ev V.A., Malysheva O.N., Maleeva I.L. Khimiia drevesiny, 1985, no. 6, pp. 94-100. (in Russ.).

31. Katkevich R.G. Khimiia drevesiny, 1975, no. 2, pp. 31-36. (in Russ.).

32. Grin'ko O.M. Eksperimental'noe izuchenie antagonisticheskikh svoistv shtamma bakterii Bacillus pumilus «Pashkov» : avtoref. dis. ...kand. med. nauk. [Experimental study of the antagonistic properties of strains of bacteria Bacillus pumilus «Pashkov": the dissertation author's Candidate of Medical Science]. Moscow, 2010, 24 p. (in Russ.).

Received September 18, 2012 
